\title{
In Vitro Reproduction and Ex Vitro Adaptation of Complex Resistant Grape Varieties
}

\author{
Batukayev A.A. \\ Chechen State University \\ Grozny, Russia \\ 2 Complex Research Institute n.a.K.I. Ibrahimov \\ Grozny, Russia \\ batukaevmalik@mail.ru \\ Batukaev M.S. \\ Agrotechnology Institute \\ Chechen State University \\ Grozny, Russia \\ Chechen Research Institute of Agriculture, \\ Grozny, Russia \\ magbatukaev@mail.ru
}

\author{
Palaeva D.O. \\ Agrotechnology Institute \\ Chechen State University \\ Grozny, Russia \\ dinna_85@mail.ru
}

\author{
Sobralieva E.A. \\ Agrotechnology Institute \\ Chechen State University \\ Grozny Russia \\ elissobr@gmail.com
}

\begin{abstract}
The research object is complex-resistant grape varieties. Intensively growing green shoots of grapes were taken as initial samples which were cut into single-eye cuttings and then meristems were extracted in laminar boxes. Experiments have shown that regeneration of shoots from extracted apexes occurred at all 6-BAP concentrations. 6-BAP has a positive effect at concentrations of $0,5-1,0 \mathrm{mg} / \mathrm{l}$. To accelerate elongation of microshoots, we studied effects of the gibberellic acid combined with 6-BAP at various concentrations. The combination of 0,5 $\mathrm{mg} / \mathrm{l} 6-\mathrm{BAP}+1,0 \mathrm{mg} / \mathrm{l}$ HK showed the best results. This combination accelerated the growth of plant stems, and two weeks after, the shoot was $\mathbf{2 5 - 2 6} \mathbf{~ m m}$ in size. At the ex-vitro plant adaptation stage, positive lignohumate effects were studied. The ability to increase plant resistance to adverse environmental factors was of special interest. The roots were put into an aqueous solution., The substrate was also watered with this solution immediately after replanting. In order to establish the optimal effect, various drug concentrations were studied. Distilled water was used as a control factor. All concentrations of lignohumate had a positive effect on plants. It is necessary to note that lignohumate increased the leaf area. At concentration of 1,0 $\mathrm{g} / \mathrm{l}$, the height of plants ha increased by the 30th day after adaptation.
\end{abstract}

Keywords - grapes, reproduction, growth regulators, in vitro, adaptation.

\section{INTRODUCTION}

Production of certified planting material of grapes is one of the most important issues of current viticulture. Viral grape diseases slow the accumulation of sugars, increase the ripening time, and reduce the yield and product quality [1]
The problem of growing plants free of viral, mycoplasmal diseases and bacterial cancer can be solved using various methods: selection and testing of visually healthy plants, use of thermo-chemotherapy and water therapy, use of apical meristems. Plants are regenerated from meristem by removing the apical dominance and carrying out a number of stages of microclonal reproduction using biologically active substances $[4,5]$.

However, test-tube plants are not adapted to environmental, non-sterile conditions. Therefore, conditions for gradual reduction of air humidity which help rebuild the transpiration system of plants and adapt to non-sterile conditions have to be created.

Analysis of research data shows that the majority of researches dealing with clonal micropropagation of fruit and berry plants are devoted to laboratory research. The most critical stage in clonal micropropagation is adaptation to nonsterile conditions in vivo $[2,6,9]$.

Various growth regulators also contribute to adaptation of healthy plants to environmental conditions. Since recently, new drugs have been used. They have positive effects on the growth and development of plants and increase their resistance to adverse environmental conditions.

\section{METHODS AND MATERIALS}

The research object is complex-resistant grape varieties. Initial samples were intensively growing green shoots of grapes which were cut into single-eye cuttings. Then meristems were separated in laminar boxes. 
The following varieties were used for the experiment purpose: Augustine, Moldova, Vostorg, Muscat Italian, Early Magarach, Magarach's Gift, Viorika, etc.

Before extracting the meristem, single-eye cuttings were sterilized in a $2 \%$ sodium hypochlorite solution. The sterilized organs were placed in a sterile Petri dish. Cover scales were removed from the top of the eye, exposing the apical meristem with primordial leaflets.

For this purpose, a dissecting needle under a MBS-10 stereoscopic microscope installed in a dustproof chamber (laminar box) was used. The meristems of 200-400 microns were extracted with a special dissecting needle and immediately placed on the surface of the agar medium in Petri dishes which were placed in the culture room under the follwoing conditions: illumination of 3000-4000 lux, temperature of $27 \ldots 280 \mathrm{C}$, relative air humidity of $65 \ldots 70 \%$. A modified nutrient medium MS (Muraseige and Skoog) with vitamins was used: thiamine $-1 \mathrm{mg} / \mathrm{l}$, pyridoxine $-1 \mathrm{mg} / \mathrm{l}$, nicotinic acid - $1 \mathrm{mg} / \mathrm{l}$, meso-inositum - $50 \mathrm{mg} / \mathrm{l}$, carbon source (sucrose) - $2 \%$, agar $-0,7 \%, \mathrm{pH}-$ up to $6,4 \ldots 6,5$.

Auxins and cytokinins in various concentrations and combinations were used as growth regulators in the nutrient medium.

The effects of indolyl butyric acid (IMC) and indolyl acetic acid (IAA), 6-benzylaminopurine (6-BAP), kinetin and gibberellic acid (HA) were studied.

Plant cultivation was carried out in Petri dishes and then in test tubes of $40 \times 120 \mathrm{~mm}$ in size. They contained $20 \mathrm{ml}$ of the nutrient medium. Explants were replanted as required. The following indicators were taken into account: survival of apical meristems and single-eye implants, growth rate of explants, formation and development of the root system.

\section{RESULTS}

The apical meristem is a cone of actively dividing cells of $0,2 \ldots 0,4 \mathrm{~mm}$ in height [3.7]. However, it can be difficult to separate a meristem without damage. Therefore, one or two leaf primordia were often separated with it.

Observations showed that at the first stage of cultivation (2 weeks), some meristems (40-60\%, depending on the grape variety), began to necrotize. One month after planting, the remaining meristems developed into micro shoots of $2 \ldots 2,5$ $\mathrm{mm}$ in size. These micro shoots were replanted into biological tubes with the same nutrient medium.

The degree of survival of apical meristems at the introduction stage for table grape varieties (Augustine, Vostorg, Italian Muscat, Early Magarach) is about $50 \%$, for technical grape varieties (Magarach's Gigt, Viorica, Rkatsiteli) is $40-45 \%$. The death of apical meristems in the process of cultivation is due to the damage of apical structures when separating.

A month after planting, the survived apical meristems were replanted into the nutrient medium containing the same components. They were replanted into biological tubes $40 \mathrm{x}$ $120 \mathrm{~mm}$ in size. Within 45-55 days after replanting, regenerants of $6-10 \mathrm{~cm}$ in size were formed. These microplants were divided into cuttings and microclones were produced.

At the cluster shoot replanting stage, the survival rate is quite high. It varies between $75 \%$ for Rkatsiteli and more than $90 \%$ for Moldova and Muscat Italian. The share of infected shoots is very low due to sterilization of apical meristems when introducing into the in vitro culture and sterile replanting (in laminar boxes).

Within 55-60 days, plant regenerants of 6-10 $\mathrm{cm}$ in size developed. Then we carried out their clonal micropropagation. Regenerant plants were cut into fragments consisting of a node, a leaf and a bud (the lower part of the internode was 1-2 $\mathrm{cm}$ longer than the top). The microcultures were planted into biological tubes $(40 \times 120 \mathrm{~mm})$ in the agar medium so that the lower part of the internode was immersed into agar. The tubes were covered with foil and placed into a culture room under appropriate conditions.

Summarizing the results obtained, it should be noted that $40 \%$ survival of the apical meristems allows for their further cultivation and reproduction and production of virus-free planting materials. Further studies were carried out using single-eye explants produced from separated apical meristems.

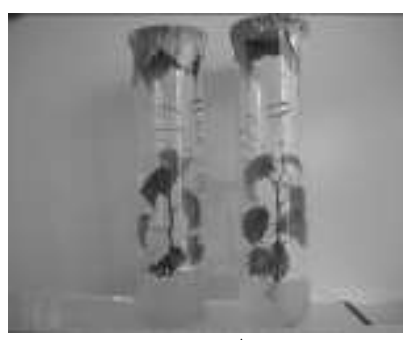

A

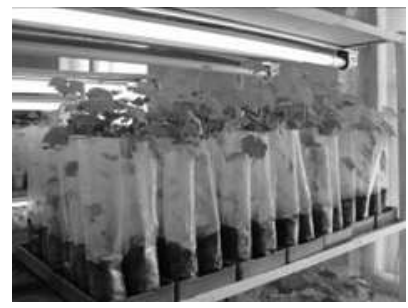

C

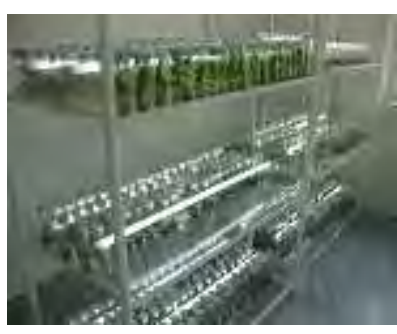

B

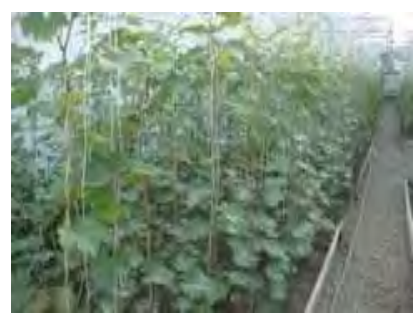

$\mathrm{D}$
Fig. 1. Plants of various grape varieties in an in vitro plant (A-B) in adaptive vessel-bags (C) growing in green houses (D)

One of the most important and integral components of the nutrient medium is growth regulators [8]. Their careful selection and identification of optimal concentrations can improve the efficiency of clonal micropropagation of grapes.

The experiments showed that regeneration of shoots from dissected apexes occurred at all 6-BAP concentrations of 6BAP, except for concentration of $5,0 \mathrm{mg} / \mathrm{l}$, when the tops immediately began to turn black and died. Micro-shoots grown in the medium with 6-BAP concentration of $0,1 \mathrm{mg} / \mathrm{l} 6$ - 
developed very slowly. This might be due to the fact that such low drug concentrations stimulate plant organogenesis weakly.

6-BAP had a positive effect in the concentration range of $0,5-1,0 \mathrm{mg} / \mathrm{l}$. Nevertheless, it should be noted the greatest increase in microshoots was observed at concentration of 1.0 $\mathrm{mg} / \mathrm{l}$.

The minimum length of microshoots was observed in variants with concentration of $0,1 \mathrm{mg} / \mathrm{l}$. At concentration of $5,0 \mathrm{mg} / \mathrm{l}$, shoot development was suppressed. This indicates that low concentrations are not sufficient for growth and development of micro-shoots, while high concentrations accelerate their development (Table 1).

TABLE I. EFFECTS OF 6-BAP ON DEVELOPMENT OF ONE-EYED INVITRO GRAPE SHOOTS

\begin{tabular}{|c|c|c|c|c|c|c|}
\hline & \multicolumn{7}{|c|}{ Concentration, mg/l } & \\
\hline Varities & 0.1 & 0.5 & 1.0 & 2.0 & 5.0 & HCP05 \\
\hline Augustine & 4.8 & 10.2 & 12.1 & 8.2 & 0.0 & 1.96 \\
\hline Moldova & 5.1 & 11.5 & 11.9 & 7.9 & 0.0 & 2.06 \\
\hline Vostorg & 5.0 & 9.9 & 10.6 & 7.2 & 0.0 & 1.84 \\
\hline $\begin{array}{c}\text { Muscat } \\
\text { Italian }\end{array}$ & 4.8 & 9.8 & 12.0 & 8.1 & 0.0 & 2.08 \\
\hline $\begin{array}{c}\text { Early } \\
\text { Magarach }\end{array}$ & 5.1 & 11.6 & 11.9 & 8.4 & 0.0 & 1.86 \\
\hline $\begin{array}{c}\text { Magarach's } \\
\text { Gift }\end{array}$ & 4.4 & 7.0 & 9.2 & 5.0 & 0.0 & 1.56 \\
\hline Viorika & 4.6 & 8.2 & 11.5 & 5.8 & 0.0 & 2.18 \\
\hline Rkatsiteli & 4.9 & 9.1 & 11.8 & 6.1 & 0.0 & 2.35 \\
\hline
\end{tabular}

In order to accelerate elongation of microshoots, we studied effects of gibberellic acid of various concentrations combined with 6-BAP. Experience has shown that the combination of $0,5 \mathrm{mg} / 16$-BAP $+1.0 \mathrm{mg} / \mathrm{l} \mathrm{HK}$ gave the best result. This combination of drugs accelerated elongation of stems. Two weeks after, shoots were $25 \ldots 26 \mathrm{~mm}$ in size. In other combinations, shoots were much lower than shoots grown in the medium containing 6 -BAP $(0,1 \mathrm{mg} / \mathrm{l})$. Thus, our experiments showed a positive effect of HA $(1,0 \mathrm{mg} / \mathrm{l})$ and low concentrated 6 -BAP $(0,5 \mathrm{mg} / \mathrm{l})$ for lengthening shoots before the rooting step.

In other combinations, shoots were much lower than shoots grown in 6-BAP at $0,1 \mathrm{mg} / \mathrm{l}$. Thus, the experiments showed positive effects of $\mathrm{HA}$ at $1,0 \mathrm{mg} / \mathrm{l}$ and lowconcentrated 6-BAP at $0,5 \mathrm{mg} / \mathrm{l}$ on the shoot length before the rooting stage.

The most important moment of in vitro plant reproduction is shoot rooting. During this period, it is necessary to ensure development of a normal root system before planting out or placing for long-term storage at lower temperatures.

Auxins are used to stimulate rooting. Given that, we studied effects of auxin growth regulators to identify optimal drug concentrations.

At the first stage, various IMC concentrations were used for in vitro shoot rooting. 15 days after, the largest number of roots was formed at IMC concentration of $2.0 \mathrm{mg} / \mathrm{l}$.
Roots continued to grow, and 30 days after, the number of roots increased. In parallel, the intensive growth of plants began, the leaf petioles lengthened, the leaf blade and the stem grew (Table 2).

TABLE II. EFFECTS OF IMC ON STEM DEVELOPMENT IN SINGLE-EYE INVITRO SHOOTS $(\mathrm{N}=20)$

\begin{tabular}{|c|c|c|c|c|c|}
\hline \multirow[b]{2}{*}{ No } & \multirow[b]{2}{*}{$\begin{array}{l}\text { IMC, } \\
\text { mg/l }\end{array}$} & \multicolumn{2}{|c|}{15 days after } & \multicolumn{2}{|c|}{30 days after } \\
\hline & & $\begin{array}{c}\text { Numb } \\
\text { er of } \\
\text { stems, } \\
\text { pc. }\end{array}$ & $\begin{array}{l}\text { Length of } \\
\text { stems, mm }\end{array}$ & $\begin{array}{l}\text { Number of } \\
\text { stems, pc. }\end{array}$ & $\begin{array}{c}\text { Length } \\
\text { of } \\
\text { stems, } \\
\text { mm }\end{array}$ \\
\hline \multicolumn{6}{|c|}{ Avgustin } \\
\hline & $\begin{array}{l}\text { Medium } \\
\text { without } \\
\text { IMC } \\
\text { (control) }\end{array}$ & 1,9 & 3,8 & 4.2 & 10.3 \\
\hline & 0.5 & 2.4 & 7.4 & 6.3 & 18.5 \\
\hline & 1.0 & 3.2 & 17.4 & 8.6 & 40.8 \\
\hline & 2.0 & 3.8 & 20.3 & 8.4 & 39.4 \\
\hline & 5.0 & 2.4 & 12.5 & 5.8 & 27.7 \\
\hline & HCP05 & & & 1.94 & \\
\hline \multicolumn{6}{|c|}{ Magarach's Gift } \\
\hline 1 & $\begin{array}{c}\text { Medium } \\
\text { without } \\
\text { IMC } \\
\text { (control) }\end{array}$ & 1.4 & 3.2 & 3.1 & 8.8 \\
\hline 2 & 0.5 & 1.9 & 6.3 & 4.0 & 14.0 \\
\hline 3 & 1.0 & 2.3 & 14.5 & 5.6 & 20.4 \\
\hline 4 & 2.0 & 2.8 & 18.4 & 5.8 & 38.3 \\
\hline 5 & 5.0 & 1.5 & 13.5 & 4.2 & 23.7 \\
\hline & HCP05 & & & 1.46 & \\
\hline
\end{tabular}

A month later, the number of rooted shoots did not increase at any IMC concentration. Only central and partly lateral roots continued to grow. It should be noted that by the 30 th day, at IMC concentration of $5.0 \mathrm{mg} / \mathrm{l}$, black roots were observed in many plants.

In order to increase the multiplication factor, two variants of growth regulator combinations were studied - 6-BAP combined with 2-iP and 6-BAP combined with kinetin. The modified Murashige-Skoog medium supplemented with 6BAP at concentration of $0,5 \mathrm{mg} / 1$ and $1,0 \mathrm{mg} / 1$ served as a control medium. One-eyed microcurrents of grape varieties Augustine and Nadezhda AZOS were planted in the experimental media. The duration of cultivation was 4 weeks, after this period, the multiplication factor and the average length of shoots were identified.

Kinetin in the nutrient medium combined with 6-BAP had a positive effect on the development of explants. Thus, in combination with 6-BAP $(0,5 \mathrm{mg} / \mathrm{l})$, kinetin $(0,5 \mathrm{mg} / \mathrm{l})$ provided the maximum reproduction rate for both grape varieties and a slight decrease in the average length of shoots. At 6-BAP concentration of $1,0 \mathrm{mg} / \mathrm{l}$, kinetin did not reduce the propagation factor of Augustine shoots. When cultivating Nadezhda AZOS explants, a slight decrease in the multiplication factor was observed: by $11 \%(0,25 \mathrm{mg} / \mathrm{l}$ 
kinetin) and 20\% (0,5 mg/l kinetin). Thus, for Augustine and Nadezhda AZOS at the micro-breeding stage, it is advisable to use $0,5 \mathrm{mg} / 1$ 6-BAP and kinetin which ensures the maximum multiplication factor.

At the stage of plant adaptation in ex-vitro conditions, positive properties of potassium lignohumate were studied. One of these properties is the ability to increase plant resistance to adverse environmental factors. The roots were treated with an aqueous solution, and the substrate was watered with this solution immediately after planting. To establish an optimal effect, various drug concentrations were studied. Distilled water was used as a control factor (Table 3 ).

TABLE III. STUDY OF POSITIVE PROPERTIES OF POTASSIUM LIGNOHUMATE

\begin{tabular}{|l|l|l|l|l|}
\hline & & & \\
\hline
\end{tabular}

As can be seen from the above data, all concentrations of lignohumate had a positive effect on plants. It is necessary to note the positive effect of lignohumate on increasing the leaf area. An increase in the height of plants by the 30th day of adaptation was observed at concentration of $1.0 \mathrm{~g} / 1$.

During the adaptation to low air humidity, slight wilting and drying of leaf blades can be observed. This is typical of lower-located older leaves due to harder rebuilding of their transpiration system. When using lignohumate, desiccation of a part of leaf blades occurred less frequently and was less pronounced. 1,0 and 2,0 g/l lignohumate prevented desiccation. Plants adapted better to lower air humidity and looked stronger and greener. It contributed to better plant survival.

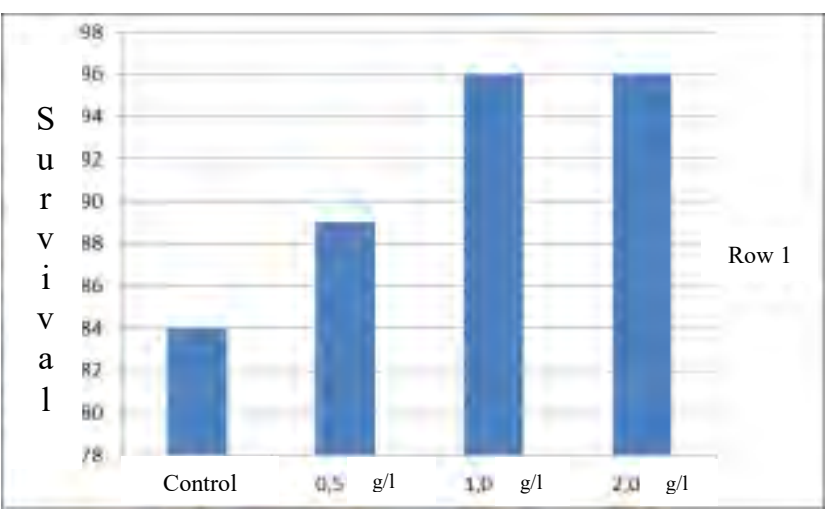

Fig. 2. The effect of potassium lignohumate on the survival of plants when adapting to non-sterile environmental conditions (Augustine)

In general, the experiment results show that potassium lignohumate $(1.0-2.0 \mathrm{~g} / \mathrm{l})$ increases the viability of adaptable Augustine grape plants.

\section{CONCLUSION}

The studies have identified the possibility of successful reproduction of the tested grape varieties using the method of culture of extracted tissues and organs in vitro due to the high potential of grapes for vegetative reproduction in general and for microclonal reproduction in particular.

The survival rate for apical meristems which are the basis for in vitro plants $(10-12 \mathrm{~cm})$ makes it possible to cultivate and propagate them (by replanting) to produce virus-free plants.

The most efficient growth regulators are regulators having concentrations of $0,5-, 1.0 \mathrm{mg} / \mathrm{l}$. For the mass propagation of shoots, $2 \mathrm{mg} / \mathrm{l}$ was the optimal 6-BAP concentration. The effect of $\mathrm{HA}$ at $1,0 \mathrm{mg} / 1$ in combination with 6 -BAP at 0,5 $\mathrm{mg} / \mathrm{l}$ accelerated the growth of in vitro microplant stems.

In the nutrient medium, kinetin combined with 6-BAP had a positive effect on explant development. Thus, concentration of $0,5 \mathrm{mg} / 1$ for 6 -BAP and $0,5 \mathrm{mg} / 1$ for kinetin provided the maximum multiplication factor for the tested grape varieties.

To improve the adaptation of grapes grown in vitro to nonsterile conditions, as well as to increase survival and improve plant quality, it is necessary to use potassium lignohumate at $1,0 \mathrm{~g} / \mathrm{l}$.

\section{References}

[1] B. Meng, B.Meng, G.B.Martelli, D.A.Golino, M.Fuchs, "Grapevirus Viruses: Molecular Biology, Diagnostics and Mamagement", Cham. Springer, 2017, p. 698

[2] S.V. Akimova, A.N. Vikulina, I.N. Buyanov, A.P. Glinushkin, "Improving the preparation of raspberry microplants for adaptation", Fruit and berry growing in Russia, T. XXXIX, 2014, pp. 16-19. 
[3] A.A. Batukaev, "Improving accelerated in vitro reproduction and planting material of grapes", M: MSHA, 1998, p. 222.

[4] A.B. Burgutin, N.V. Butenko, P.Ya. Kataeva, "Rapid clonal propagation of grape plants", Golodriga, p. biology, 1983, № 7, pp. 48-50.

[5] A.B. Burgutin, V.A. Vysotsky, "Biotechnological techniques in modern gardening", Collection of scientific works of the All-Union Academy of Agricultural Sciences, T. XXVI, Moscow, 2011, pp. 3-10.

[6] V.I. Demenko, K.A. Shestibratov, V.G. Lebedev, "Rooting as a key stage of in vitro plant reproduction", Proceedings of the TAA, 2010, vol. 1, pp. 73-75.
[7] M. Carre, J. Martin-Tanguy, P. Mussillon, "La cultur de meristemes et la multilpication Végetative in Vitro au service de la pepiniere", Bulletin Petits Fruit, 1979, vol. 14, pp. 7-65.

[8] K.Z. Hamburg, N.I. Rekoslavskaya, S.G. Shvetsov, "Auxins plant tissues and cells", Novosibirsk: Science, 1990, p. 243.

[9] N.V. Kucharchik, MS Kastritskaya, S.E. Semenas, E.V. Kolbanov, "In vitro reproduction of fruit plants", Minsk, 2016, p. 208. 